\title{
Stress in Organizations: between Efficiency and the Institutionalization of Fear
}

\author{
Flávio Carvalho de Vasconcelos* \\ E-mail address: fcvasconcelos@gvmail.com \\ Escola de Administração de Empresas de São Paulo (EAESP) - Fundação Getulio Vargas (FGV) \\ São Paulo, SP, Brazil.
}

Isabella Freitas Gouveia de Vasconcelos

E-mail address: isabellav@fei.edu.br

Fundação Educacional Inaciana Padre Saboia de Medeiros - FEI

São Paulo, SP, Brazil.

João Marcelo Crubellate

E-mail address: jmcrubellate@terra.com.br

Centro Universitário Positivo - UnicenP

Curitiba, PR, Brazil.

\begin{abstract}
Sometimes organizations described as benevolent, focusing on stable procedures and cordial relations are regarded as examples of collective indolence and likely to be out-competed by aggressive, merciless and stressprone organizations. In this paper we suggest that some managers and organizations follow a requisite stress principle, according to which stress inside organizations is treated as a variable to be equated to the stress level perceived to prevail in the institutionalized environment the organization operates. We thus predict the relationship between stress-inducing practices, individual responses and performance to be recursively explained. When organizations induce stress at levels that are different from those admitted institutionally as normal levels, there will be a negative response to this induction. When induced stress levels are considered excessive, activities will be inhibited because fear will control the capacity of people to deal with situations and act in an appropriate manner. The validity of this principle implies that control of stress in organizations is as complex as the level of stress in society: it will depend on the control of stress levels coming from society. The principle consequently puts an end to any management aspirations to use stress as a managing mechanism and for inducing behavior.
\end{abstract}

Key words: stress; fear; stress management; institutional environment.

Received 06 July 2005; received in revised form 21 February 2006.

Copyright (C) 2008 Brazilian Administration Review. All rights reserved, including rights for translation. Parts of this work may be quoted without prior knowledge on the condition that the source is identified.

*Corresponding author: Flávio Carvalho de Vasconcelos

Av. Nove de Julho, 2029, $9^{\circ}$ andar, São Paulo/SP, Brazil, 01313-902. 


\section{INTRODUCTION}

The notion is currently very popular that organizations that are noted for their stable working procedures. Cordial internal and external relationships and friendly atmosphere are examples of collective indolence and tend to lose competitive advantage vis-a-vis more aggressive organizations that look for continuous innovation and that have working relationships marked by change and stress (Aubert, 1990; Hirchhorn, 1997).

This notion, which is mainly popular in that strand of writings dealing with administration and managing people, is based on the assumption that advocates the possibility of, and even the need for, management by stress and fear as a necessary motivator of ideal behavior on the part of workers. This possibility is however questioned and denied by various strands of organizational theory and by various analytical currents of people management. Even so it continues inspiring the actions of managers and organizations alike which, without the support of any empirical indicators in their favor, keep adopting policies and practices that induce fear and anxiety and consequently create stress among employees, as a way of obtaining greater productivity and efficiency (Mangematin \& Thuderoz, 2003).

This article aims to explore the possibility of providing a response to those actions that are deliberately directed at the control and strategic use of stress in organizations. Based on the institutional theory in organizations and on the notion of recursiveness between structures and social actions, we have tried to put together a study proposition that will allow for both explaining the use of stress and fear induction, as well as dealing with the consequences from the point of view of those workers who are submitted to these techniques.

We propose that these aspects can be described by means of what is called in this article, the principle of necessary stress, which allows for some degree of equilibrium between the predominant intentions within the internal context of organizations - between managers and workers - and the degree of legitimacy that these intentions receive from the external environment; the most important and fundamental aspect of this equilibrium is to be found in the process of interpretation by organizational agents.

With this proposal we intend also to offer an alternative for understanding the important aspect of human behavior in organizations that goes beyond the approach that is merely behavioral and centered on the individual because it brings together and makes the specifically individual aspects that are centered on agency capacity interact with aspects of a social nature - interpretation and legitimacy, linked mainly to what conventionally is defined as the institutional environment. Consequently we have a systemic explanation of stress in organizations, its intended use as a management resource and the levels of conformity in relation to those attempts.

\section{Stress in Organizations: Fear Management and fear as a Management RESOURCE}

Definitions of stress in organizations vary from it being conceived of as based on the type of response of individuals to the circumstances that are presented to them, to being conceived of as a process that can be directly stimulated by external conditions (Perrewe \& Ganster, 1989). In general, stress is conceived of as anxiety and dissatisfaction (Perrewe \& Ganster, 1989). Research into stress within the sphere of social and organizational psychology in general dichotomizes the explanations as far as its origins are concerned, acknowledging that contingent elements, or individual psychocognitive elements, are sufficient explanation for its appearance among workers. The dispute therefore comes down to the definition of stress as an individual response, or as an environmental factor that 
causes certain psychological reactions (Caplan \& Jones, 1975; Matteson \& Ivancevich, 1987; Perrewe \& Ganster, 1989).

As Meyerson (1994) also suggested, the strongest tradition in the studies into stress in organizations assumes that stressful circumstances are necessarily harmful to individuals, and therefore undesirable. She suggests that in these studies the classic dichotomy of objective vs. subjective prevails as an explanatory parameter for the antecedents of stress, in other words, the localization of the sources of it in objective contextual conditioners, or alternatively, the attribution of stress strictly in the way that individuals perceive and interpret their experiences. In this latter sense the whole of the problem is located purely in the individual and, generally speaking, the importance of contextual conditions is either denied or ignored.

Cropanzano, Howes, Grandey and Toth (1997, pp. 164-165) also defined stress as "[...] the subjective feeling that work demands exceed the individual's belief in his or her capacity to cope [...]", which creates the sensation of anxiety and tension that in turn are the evidence of stress. These authors believe that these circumstances can be costly for organizations and individuals to the extent that they generally result in an enormous loss of time, a reduction in production and the occurrence of accidents. The perception of the workers with regard to organizational policies and the support that organizations offer are determining factors in the level of stress among workers.

But, in fact, if the suggestion of Meyerson (1994) is accurate when she points out the tradition of organizational studies relating to stress, it reveals, above all, the degree of innocence with which the issue is handled, since generally speaking this tradition omits the possibility of any intentional strategic use of the circumstances for obtaining responses and actions from the organizations that are considered desirable as far as the people engaged in them are concerned.

For example, Parasuraman and Alutto (1984) analyzed a series of contextual and personal factors that are related to the role occupied in the organization as being factors that play an intermediary role between the elements that cause stress and the attitudes and behavior of workers in relation to these elements ('job stressors'). In this model we can see that discussion of any underlying intentionality, or the strategic use of processes based on the spreading of stressful situations or elements, are avoided. Likewise (and more importantly for purposes of this paper), the analysis introduced by these authors is strongly endogenous, in other words, the contextual characteristics are only admitted as intervening elements in the perception of those elements that cause stress. They are looked at only within the sphere of the organization itself and within the context of the most immediate work (characteristics of the task, type of leadership, organizational level of operation), and at no time is the possibility of a relationship between stress (either its intentional use or its occurrence or even the perception of it on the part of the workers) and wider institutional conditions, or of it being the result of the institutionalization of the process, ever considered.

The problem of stress is thus limited to the organizational plan, as if referring to an undesirable consequence of organizational life and work, thereby hoping that in this way it will be eliminated, or at least minimized.

It was in this sense that Perrewe and Ganster (1989) developed their study, by looking to analyze organizational intervention that is carried out with the intention of reducing or eliminating stressful conditions that become apparent in the working environment. According to the authors, these interventions do not merely result in the construction of factors that absorb the impact of the stressful environmental characteristics, but also in the putting together of mechanisms that can alter the perception of individuals as far as their own context is concerned, since this aspect is also recognized as a source of stress.

Therefore, stress management implies both intervention to eliminate stressful factors, as well as training employees to deal better with situations that cause stress. However, for Perrewe and Ganster (1989) there is a certain reluctance to recognize the need for the second stress management mechanism 
and, according to them, this is due to the fear of managers that, by increasing tolerance to stress, these training mechanisms lead to a consequent decrease in productivity.

This notion implies recognition of the common belief that a degree of stress is necessary for maintaining productivity at work. Perrewe and Ganster (1989) assumed this belief when they explained that the reluctance of managers is partially justified by the absence of studies relating stress management to an increase in productivity. In this sense it seems plausible to conclude that what is called stress management explicitly admits the need to control stress levels among employees, but at the same time does not implicitly deny the managerial premise of the need for some degree of stress for maintaining productivity. The idea of stress management, therefore, can be pointed to as referring, if only partially, to the strategic use of stress as an element for controlling and managing individuals within the context of work. It is not the elimination of stress conditions, but their control at levels that in some way, or by some criteria, are considered optimum for provoking the hoped-for and desired reactions from workers.

Using a contingential argument on the other hand, Fenwick and Tansig (1994) related the perception or sensation of stress to macro-economic conditions, by suggesting an addition to the literature that emphasizes immediate working conditions as a source of stress. For them macro-economic conditions are important factors when it comes to determining working conditions in organizations and, in this way, may be indirectly, or even directly, cited as stressful factors. It should be noted that, despite their contingential and deterministic focus, a broadening of the explanations for the rise or maintenance of stress conditions outside the purely organizational sphere already figures in Fenwick and Tansig (1994).

In literature on stress there are three notions that predominate: stress is either defined as a product of environmental stimuli (Kahn \& Byosiere, 1992), as the individual response to environmental characteristics, or finally, as the maladjustment of the individual to environmental characteristics (Caplan, Cobb, French, Harrison, \& Pinneau, 1975). In all these possibilities stress is seen as a dependent variable. The counterpart to this vision is given in the literature on stress management, which attempts to think about stress (and, in a more managerial way, fear) as an independent variable related causally to productivity and efficiency at work.

In this sense there are various authors who mention the positive consequences of stress at work (Ayres, Brito, \& Feitosa, 1999; Fontana, 1994; Lipp, 1996). For Fontana (1994) stress is the natural result of the current living conditions in modern society; it is desirable if managed at minimum levels. Lipp (1996) on the other hand actually talked about 'positive stress'. The majority of these approaches avoid criticizing stress management, or its causes - anxiety, insecurity, in short, fear. Guided by traditions that are linked to Social Psychology, however, this criticism is going to be explicitly developed.

For Enriquez (1990) different forms of social control are at the heart of the occurrence of pathologies, both social as well as those that manifest themselves within the context of work. Among these forms, control based on force or violence - direct control - is especially related to fear, but other more recent and subtle forms are related to the symptoms and consequences of fear, and therefore to stress, which is becoming increasingly a social pathology. In these ways, the control of results - or actuarial control - significantly affects workers, both in the physical as well as the emotional sphere.

Control of results follows the Taylorist logic of prescribing the amount and way of working considered minimal and ideal, and from the standards prescribed, the verification and evaluation of workers. The problem can be summarized as a generalization of the effort on which it is based and on the criteria of justice implied: the imposition of excessive effort, and the interpretation of this as an unjust condition by the workers, creates physical problems and above all fear and stress.

The study of Couto and Moraes (1999) for example, indicated precisely this condition, i.e. the negative consequences, both physical and psychological, that arise from a form of control based on a definition of standard effort, to be used for measuring and evaluating the activities of supermarket 
check-out operatives. Control, based on the number of key touches per minute, in addition to physical injury, causes above all tension, oppression and consequently stress. The consequence is that the increase in productivity generated by the imposition of this control mechanism is frequently limited by the greater incidence of lesions and consequently the worker being off work (Ayres, 2000) or, at least, suffering highly psychological costs (Couto, 2000). This is notably a procedure that demands there should be the possibility of substituting the worker easily and cheaply.

Most of these studies (see also Moraes et al., 2001; Sant'Anna, Costa, \& Moraes, 2000) locate the source of stressful factors not only within the organizational context, but above all in the modern-day way of life and work. Anxiety and fear are in general seen as stemming from the modern way of life, with stress being a peculiarly modern sickness (Albrecht, 1988; Sant'Anna et al., 2000). These authors - particularly the latter - also admitted the possibility of some benefit resulting from stress, if not for the workers, at least for the companies.

Dejours (1999) located the source of fear and stress in the work-related activities of modern institutions, but evaluated them in the opposite way to Albrecht (1988). For Dejours (1999) it is precarious working conditions that allow managers and organizations to use fear and stress as a way of controlling and a means for tentatively increasing organizational productivity. The fundamental difference lies in Albrecht's (1988) acceptance of the moral validity of this scheme, as opposed to its rejection by Dejours (1999) and other authors who adopt a psychoanalytical and critical line.

In organizational psychodynamics various authors apply the psychoanalysis model to deal with anguish and the way in which groups deal with it as a result of their interaction. These authors show how rules serve to protect the individual from his internal anguish by supplying a safe daily life and routine, which because it structures his time, allows him not to be at the mercy of his internal driving forces. Along similar lines, Enriquez (1992) also shows how current organizations, using their ideology, try to help the individual deal with his internal anguish by supplying him with a sense of life and continuity by creating career and culture plans that try to integrate the individual into the broader system.

Fear, therefore, differs from anguish. Fear, as defined within the psychodynamics of work, deals with the anxiety and stress generated by risks that are inherent to professional activity and produced by this activity. We are, therefore, dealing with a specific set of stress and anxiety reactions generated by situations linked to the professional activity and to the exercise of a given profession.

Dejours defines the different ways of fear linked to work: initially there are sensations of anxiety, related to the degradation of the mental functioning and the psycho-affective balance (Dejours, 1995). Working environments, where a model of leadership classified as paranoid by Ketz de Vries and Miller (1985), predominates, produce this type of fear. In this type of company, those responsible for administration adopt a line of constantly suspicious conduct, mistrusting and doubting not only people, but also things that happen both within and outside the company.

Ketz de Vries and Miller (1985) also described other types of organization: the compulsive organization is one where paranoid practices are already firmly set in place, thus causing stress because of its meticulous and dogmatic attitudes. The excessive application of rules is predominant in this domain, because of the fear of making mistakes. But anxiety linked to making mistakes can cause even more mistakes to be made, leading to reinforcement of the controls; this comes very close to the idea of the self-fulfilling prophecy. In the same way, stress is due to hyperactivity in theatrical organization, to apathy and conservativeness in depressive ones and to the fragmentation of authority in schizoid organizations. Despite (or because of?) the evil consequences of fear at work, at least from the perspective of psychodynamics, the intentional use of fear as a resource for producing more involvement with work has to be recognized.

Vasconcelos and Crubellate (2004) criticized management based on fear and stress in their research, which is mostly based on pointing out the relationship between the broad institutional context and the discursive validation of some of the labor conditions. In fact the use of fear as an institutional 
management strategy, or its institutionalization as a way of managing, seems to be clear in its close link to the predominant 'fashions' in management over the last few decades, such as re-engineering, downsizing (Ferreira \& Tomei, 2004) and voluntary redundancy programs. What we intend to do here is develop arguments that are favorable to the hypothesis that this institutionalization of fear and stress does not only occur at the macro-social level, but can also be seen at the more local level within organizations and in their management practices.

\section{The Institutionalization of Organizational Processes: the Mimetic Hypothesis}

In organization theory the institutional approach represents a reaction against a concept that has been predominant for some decades and that conceives of organizations as closed and completely autonomous systems that are truly rational agents (Scott, 1992; Scott \& Meyer, 1994). If, as fully rational agents, decision makers, and the organizations under their management, are understood as taking decisions using criteria that maximize interests, in the institutional theory what is mainly discussed are the social limits that affect full knowledge of the context of the operation and, as a result, of the achievement of these interests. As has been seen recently this is not a question of denying the rational nature of human agents or organizations, but of trying to understand their limits as a result of the social immersion necessary for the action itself (Granovetter, 1985; Scott, 2001).

One of the most important strands of the institutional theory in organizations (DiMaggio \& Powell, 1991, 1983) points to the existence of a general trend in the direction of standardization. This is because organizations look for support and legitimacy in their institutional fields by adopting structural models that are generally perceived as being the best models available. So international standards organizations, such as ISO (International Standards Organization), which is responsible for many types of industrial norms, have a key role to play when it comes to defining the isomorphic properties of many institutional fields (Guller, Gillén, \& Machpherson, 2002).

Social actors and organizations adopt institutional and cognitive models not only because they perceive them to be the best alternative, but also because they are rewarded when they do so by an increase in their legitimacy within their particular field of activity, thus increasing their access to certain resources and in the final count increasing the survival chances of the organization. The neoinstitutional theory suggests that an institutional sector is a space that brings together many organizations all competing for scarce resources. Institutional sectors are characterized by the elaboration that the organization conforms to, in the sense of being recognized as a legitimate player and in the sense of obtaining support for their social actors and organizations (Scott \& Meyer, 1983).

Important neo-institutional theoreticians propose a process typology that leads an organization to change its structures and management practices to adopt an institutionalized normative model (Powell \& DiMaggio, 1991; Scott \& Meyer, 1983). Professional associations, international standards organizations and government entities are important actors in the process of creating and molding organizations.

According to these authors each institutional sector is witness to the confrontation between the many standard models that are engaged in a symbolic battle, at the end of which a small group of normative models is recognized as being efficient and suitable for this specific institutional sector. These models, therefore, represent the balance of power in the sector, thus reflecting the relative prestige of each actor or organization.

According to institutional theory (mainly DiMaggio \& Powell, 1983; Mizruchi \& Fein, 1999) organizations adopt institutional models using four basic isomorphic processes: coercion; induction; appropriation (mimetic organizational behavior); and normatization (authorization, adoption of norms). It suggests, too, that the formal structures of many organizations in post-industrial society reflect the myths of their institutional environment instead of the requirements of their working 
activities. Norms, technology, procedures and cultural issues can be seen as highly institutionalized structures that function as myths. These institutionalized technical procedures are taken for granted as being necessary for achieving the organization's objectives. They are considered to be the best tools available and their adoption is the source of their legitimacy. By using them, organizations avoid being accused of negligence. As Meyer and Rowan (1977) pointed out, organizational structures are created and put together with the ascension of institutionalized myths and, in a highly institutionalized context, organizational activity must be divorced from real practice. But an organization must also deal with its practical activities.

Many researchers have concluded that there is a wide gap between formal and informal organizational structures. As Meyer and Rowan (1977) also pointed out, organizations in the same industry tend to be similar in their formal structure because they have common institutional origins, but can demonstrate a great deal of diversity in their actual practices. This analysis logic ends up admitting that there is a necessary dichotomy between the technical and symbolic dimensions of organizational structures.

Meyer and Rowan (1977) admit that organizations are increasingly characterized as reflecting the institutional standards of the context within which they operate, rather than the technical demands related to their operational activities. Therefore, these authors discuss the institutional nature of organizational structures, processes and programs, which are apparently technical aspects, but which for them can be better described as projections of the myths that predominate within the organizational environment. For them institutionalization is "the process by which social processes, obligations, or actualities come to take on a rule-like status in social thought and action” (Meyer \& Rowan, 1977, p. 341). This corresponds to a social rationalization logic in the sense that institutionalization is a gradual process of justifying certain practices or options, which therefore become legitimate, and at the same time legitimizers of the groups that incorporate them, regardless of any criteria of efficiency or technical usefulness.

This observation is important when it comes to understanding the symbolic nature of organizational structures and practices that are therefore understood as rational myths, since they are mainly adopted using culturally based mechanisms of diffusion and social cognitive conformation (Meyer \& Rowan, 1977), even though outwardly they present themselves as the purely technical aspects of organizations. For this same reason they might be ceremonially adopted as a strategy for obtaining legitimacy vis-àvis the environment rather than for solving problems of a technical or operational nature.

Along these same lines, institutionalized structures and practices can cause the occurrence of the decoupling phenomenon, a circumstance in which a misalignment, or disconnection, between formal structures and the activities carried out by the organization, occurs (Meyer \& Rowan, 1977). This phenomenon arises from the contradictory pressures that arise between the search for institutional legitimacy and operational efficiency: sometimes when dealing with institutional and technical criteria the organization has the necessary operational standards for efficiently controlling and coordinating its activities, but at the same time there are elements in the formal structure that are decoupled, or disconnected one from another, and above all disconnected from these activities, with the intention of not losing legitimacy vis-à-vis their social environment.

One of the relevant points of this theoretical line is an analysis of institutionalization as a process that affects the thoughts and actions of the social actors, but without denying them space for autonomy. In other words it does not equate institutionalization with loss of autonomy even if this autonomy does not occur on the symbolic plane, but only on the technical plane (in this strand, institutionalization is the diffusion of those meanings that may be adopted, quite regardless of any substance or concrete action).

Following a purely rationalist analysis logic, acceptance and the spreading of management practices based on fear and which allow stressful working circumstances, might be justified by the causal relationship between such practices and an increase in the efficiency and productivity of the workers. Despite defense of this relationship in some contexts and by some researchers, as previously observed, 
there is also strong criticism with regard to this relationship. At the very least it cannot be classified as real in all those working contexts where nowadays stress becomes the main element in the environment. This suggests a questioning of the rational premise for explaining the spread of practices that are based on fear and stress.

On the other hand, following the logic of isomorphism as an institutional mechanism for spreading standards, and the logic of institutionalization as the spreading of meanings, it seems plausible to put together a research hypothesis for analyzing the adoption of people management techniques that use fear and stress as mechanisms for control. Mechanisms of institutional isomorphism, and principally mimetic isomorphism, might explain situations in which fear is seen as a motivator in organizations. In this case, to formally adopt procedures and practices that induce fear and cause stress might be considered by some managers as a way of promoting a specific institutional image of their organization, or may even be their way of acting within the organization, thereby obtaining the respect of other organizations and even of other social actors in those contexts where this behavior is perceived, or rather institutionalized, as a legitimate and necessary mechanism for maintaining organizations.

Basically, it seems possible to admit that in social contexts where fear and stress are considered normal conditions under which to work, managers will adopt formal management procedures based on the spreading of fear and stressful conditions as mechanisms for controlling and motivating their employees, with the idea of obtaining legitimacy vis-à-vis other organizations, other managers and the other social actors present in the organizational environment.

This seems to be the case in some working contexts, such as, for example, those of executives (see Vasconcelos \& Crubellate, 2004, for instance), flight controllers or people involved in high risk operations (in nuclear power stations, for example), which, it is apparently agreed, are highly complex activities (Perrow, 1999; Weick \& Sutcliffe, 2001) that demand quick decisions and where a mistake might cause the loss of large amounts of money, or put at risk the lives of thousands (at times, millions) of people.

The same institutional theory also suggests that the absence of an obvious relationship between environmentally prescribed practices and operational efficiency should create a circumstance of disconnection between the apparent, symbolic dimension and the concrete, operational dimension of organizational structures and processes (mainly in Meyer \& Rowan, 1977). This is not what we see, however, because alongside the formal structures, or in addition to them, actual control practices based on stress are being used - sometimes without the resource of the symbolic dimension, or by trying to disguise this dimension - with the clear idea of obtaining efficiency and greater productivity (see, for example, Crubellate, 2003; Rossini, Crubellate, \& Mendes, 2001).

This theoretical circumstance seems to demand we go deeper into the explanations surrounding the institutional theory so that we can better describe the current context of practices for managing people based on fear and stress, without having the necessary evidence regarding their impact on operating efficiency. This in-depth examination is done by analyzing those recent studies based on institutional theory in organizations that attempt to analyze the rational dimension of human and systemic behavior within an institutional logic that goes beyond the unconscious and deterministic spreading of standards that are environmentally prescribed. This review follows; at the end of it we put forward a second research hypothesis.

\section{UNDERSTANDING THE GROUPING IN THE RELATIONSHIPS BETWEen STRESS/FeAR, EFFICIENCY AND THE INSTITUTIONAL ENVIRONMENT: A SYSTEMIC-RECURSIVE HYPOTHESIS}

If it is accepted or demonstrated as being valid, the mimetic hypothesis presented above suggests a situation in which, either fully or mainly, there is a growing symbolic adoption in organizations of 
management practices that induce fear and stress, because we see growing criticism of the possibility that there is a relationship between levels of stress and levels of efficiency, or productivity at work. As a result of the lack of any indication of the relationship between real levels of stress and productivity, mistrust as to its validity as a management technique is growing. This creates a situation that may be considered contradictory as far as the mimetic hypothesis previously mentioned is concerned: there seems to be no symbolic support for the use of stress (it becomes increasingly non-legitimate as an instrument for inducing behavior in companies), but continues to be increasingly used.

Note that we are not denying the validity of the mimetic hypothesis. Since we are still dealing with this discussion on a purely speculative level, what we intend to explore are the theoretical possibilities for explaining the phenomenon of the spread of techniques for inducing behavior using fear and stress in organizations. What we are specifically proposing at this point in the discussion is an attempt to bring other institutional elements into the discussion and, by doing so, bring about the possibility of putting together another institutional hypothesis for explaining this phenomenon.

Beyond the mere explanation of the spread of similar social standards by means of cognitive mechanisms the institutional theory has more recently been dwelling on the possibility of also understanding social and organizational change as being the possible result of the institutionalization process. As a result of the sociological considerations coming from authors like Giddens (1984) and Luhmann (1995), with their heavy emphasis on the intermediation of interpretative mechanisms in the relationship between environmental determinations and the responses of social actors (individuals, organizations, social systems), a recursive theory of the process of institutionalizing organizational standards has been formulated.

From the sociological perspective, institutions are not only understood as limiters of these practices, but also the social framework within which these practices can take place. In the same way, social actors and organizations are understood not only as passive respondents vis-à-vis institutional determinations, but also the very constructors of these institutional structures. The environment itself, and therefore from this point of view, its institutions, become contingent in relation to the responses and to the agency of the social actors (Luhmann, 1995; McKay, 2001). This perspective can make considerations arising from classical theories on stress in organizations imprecise when they suggest that stress is only the result of macro-environmental conditions (mainly economic, but also social), or the way in which individuals interpret these conditions. From a recursive perspective, in order to better understand the way in which stress is generated and reproduced within the context of work, we have to consider this double phenomenon, i.e. environmental conditions and their individual, organizational or systemic interpretations.

As we have seen, the idea of a systemic level of observation of these relationships has been used many times in this text. This needs to be better explained. One of the main notions of the systemic theory is the idea of the dynamic equilibrium between the system and the environment.

The fundamental logic of this type of argument can be linked to the origins of cybernetics in the 50s when W.R. Ashby put forward the requisite variety principle. According to this principle the complexity of a control mechanism increases proportionally with the complexity of the system that it is supposed to control. In the words of Ashby (1957, p. 207) when analyzing the relationships between control mechanism, R, and the system controlled, D: "This is the law of Requisite Variety. To put it more picturesquely: only variety in $\mathrm{R}$ can force down the variety due to $\mathrm{D}$; variety can destroy variety". Variety in the control mechanisms is going to depend on the variety in the system to be controlled and at the same time it will also be the way by which that variety in the system can be controlled. Therefore, the optimum control level always occurs when equilibrium between the variety in the controlled system and the variety in the control mechanism is achieved.

Later in the 60s this principle was used as the theoretical foundation of the contingency theory (Burns \& Stalker, 1961). More recently the systemic theory has become more complex with (mainly) Luhmann's (1976, 1995, 2002) extension to its philosophical and sociological basis, including phenomenology as a complementary resource to functionalism for analyzing social systems. For 
Luhmann the relationship between systems and environments that is linear in terms of the traditional systemic theory (as for example in the principle proposed by Ashby) is described as being intermediated by the operation of the systems themselves. Instead of the notion of social systems as open systems, for Luhmann (1995) social systems are, at one and the same time, both open and closed: the way in which they adapt to the environment is always determined by a logic that is peculiar to each type of system and not determined by any external environmental consideration.

In the case of human beings or organizations this adaptation logic refers specifically to the process of interpretation: human beings and social systems construct meanings in relation to what goes on around them and these meanings prompt their responses.

This new perspective has implications for the analysis of stress in organizations. As we have previously observed, provoking fear as a management practice within organizations is not something that is necessarily new. For a very long time Behavioral Psychology has been studying threat and fear as generators of action, suggesting that there might be an optimum level of fear when it comes to obtaining persuasion. In research into the behavior of the consumer and in the field of marketing strategy the use of threat and techniques for awakening fear - i.e., the use of threats or appeals to fear to provoke certain responses (for example, showing death by AIDS as the result of unsafe sexual behavior) - is well accepted (despite some ethical discussions) as an effective technique for persuading consumers to buy products, services or ideas.

From the systemic notion of equilibrium between systems and environments and principally since the recent extension of that systemic theory to include notions of recursivity and interpretation as necessary processes for understanding the relationship between people, systems and environments, it is suggested that stress and fear in organizations can be treated in accordance with a principle similar to the requisite variety principle; we might call this the requisite stress principle. When we are dealing with the organizational level of analysis, the requisite stress principle states that stress within organizations is treated as a variable to be equated with the level of stress that is interpreted as predominant in the institutional environment in which the organization operates and tries to be successful.

Therefore, we suggest that organizations - and in particular their top strategic management - will try and induce or decrease fear and stress to the levels that are perceived as being necessary, in the sense of adapting organizational energy and/or activity, and by doing so generate sufficient impetus for subordinates to fulfill their organizational tasks and positively accept the challenges imposed on them. It is therefore proposed that the use of these mechanisms for inducing stress, as far as dependence on determinations coming from the social structure in force is concerned, can be explained when we analyze the legal-regulatory, normative and cultural-cognitive contexts within the overall institutional context in which the top echelon in an organization believes it is acting, or intends to act. There will always be an effort, sometimes intentional and sometimes unconscious, to reach or maintain a balance between the stress level induced in the organization and the levels considered normal outside the organization.

On the other hand the effectiveness measure of these attempts at achieving a balance between internal and external levels of stress will depend on the interpretive processes created by those people (not in isolation, but developed from their social experience) who are submitted to these attempts, principally when related to intentional efforts, and if the recursive notion is correct.

From the point of view of people submitted to these stress and fear induction techniques, such techniques can be described as environmental impositions. Therefore, they will receive responses in accordance with the definition and interpretation of the people submitted to them; these responses may be positive or negative in relation to what is determined. It is therefore suggested that stress becomes ineffective when it is interpreted by employees as not legitimate. If the environment defines it as legitimate (legally or from a norm point of view), or necessary (cognitively valid), then people tend to accept it and it becomes positive. Under these circumstances those levels of stress in organizations that are below or above the levels considered legitimate may constitute a problem: in the first case people 
may feel not stimulated and not valued enough if the work environment is more benevolent than is presumed necessary or normal within the organization's social context of reference. On the other hand, when levels are interpreted as being above those defined as institutionally legitimate, which is much more relevant as far as the objectives underlying our purpose in this text are concerned, people will tend to define the work situation negatively and reject stress induction.

So, when it is a question of the analytical level of people submitted to an attempt to create activity by spreading fear and stress, the requisite stress principle would state that the effects of stress in an organization will depend on the predominant interpretation within the social context and within the organization as to what are considered normal working conditions: when organizations induce stress at different levels than those that are institutionally admitted as normal (according to the interpretation of people submitted to induction programs), there will be negative responses to the induction. When the levels of induced stress are considered excessive they will inhibit activity, because fear will control the capacity of the people to deal with the situation and to act in an appropriate way.

Note that here we are repeating the notion of dynamic equilibrium as proposed by the systemic theory. However, what we wish to highlight, in addition to the phenomenon of stress as the object of the proposition (a specification of the variety generically proposed by Ashby), is that the central point of this equilibrium is the interpretation mechanism. In the final analysis it is this mechanism that is going to determine the direction of the adaptation process. Furthermore, we would also highlight the fact of reference to the institutional context as the sphere in which that interpretation is given. So, if the proposition of the meaning attributed to the level of stress comes from the neo-functionalist theory (Luhmann, 1995), the suggestion of the socially immersed nature of this meaning, i.e. understanding it as the product of social relationships and not a purely cognitive individual product, relates the requisite stress principle to the institutional theory as another necessary basis for establishing it.

A third aspect that needs to be highlighted is the linear relationship between variations in the environment and the system accepted by the principle proposed by Ashby. Note that in the requisite stress principle this linearity is only partially maintained: we might admit that the meaning attributed to the efforts for inducing fear and stress will depend on the meaning attributed to stress and to fear within the institutional context of the organization and the people that work in it. As a result, acceptance, or otherwise, of induction efforts will also be subject to this linearity, to the point that acceptance of these efforts depends only on the meaning attributed to them. Obviously there are psychological and even physical aspects implied in high levels of stress that can, when they occur, affect this acceptance and even lead to a break with the predominant meaning.

We also need to underline that from the perspective of institutional theory reference to the social context, which should be the fundamental element in the process of interpreting the mechanisms of induction, will occur in relation to what is considered legal and legitimate in norm terms and also to what is cognitively established as a normal standard of stress within the context of work. In this latter case it might not be possible to describe this standard rationally: even if people do not recognize it as such, it is taken for granted as the standard that guides them.

\section{FinAl Considerations: CoMments AbOUT FeAR AND StRess MANAGEMENT}

In general, issues relating to human behavior in organizations have been analyzed in specialist literature from explanatory voluntarist or deterministic perspectives. As far as stress is concerned these dichotomous visions help to encourage belief in the possibility of fear and stress management within the corporate sphere. This belief arises from the paradoxical circumstance inherent in that dichotomy: when one believes in the voluntarist character of reality, i.e., as being entirely the product of human will, we can conclude as a result that it is possible to plan it and control it intentionally. On the other hand, when one believes in the determined character of human nature one can also believe that the domain of contextual conditions will inexorably signify the domain of behavior, or the human 
responses to that context. There is therefore a circularity here, where people can create the contextual reality and this reality in time will determine the behavior of people.

The paradoxical condition is that, in these terms, the circle turns in on itself, not giving scope for the possibility of any change whatsoever. Conventionally this circular condition is resolved in management and strategic literature in a simplistic way. Thee simplistic solution consists in suggesting that some people have - for inexplicable reasons - the capacity to rise above, or outside this circle, and interfere in reality without being conditioned by it. These individuals - strategists and managersmanage therefore to affect the context, intentionally plan it and, in this way, condition the behavior of other individuals.

The paradox of simple circularity that prevails in the majority of the conventional theories on stress management may even contribute to partially explaining why some things are so difficult to change. But it does not help us when it comes to understanding why other things change with such frequency.

In terms of the theme of stress the two predominant currents represent trends in this sense. We either admit in a voluntarist way the possibility of the organization imposing stress management mechanisms as a way of encouraging desirable behavior and avoiding undesirable behavior, as though human responses can be motivated directly, or in another sense that is linked to psychoanalysis, these mechanisms are the result of the perverse face of the personality of the managers. In the second possibility the elaboration of control mechanisms based on fear is generally understood as a projection of the personality structure of the managers, and despite the difference in definition as to the source of these mechanisms, the assumption is maintained of this possibility: the possibility, or not, of the direct affect of the mechanisms on the people that are submitted to them is not discussed. It is on this point that the institutional theory offers an alternative explanation for that affect without involving the supposition of direct control.

In this sense one of the assumptions that underlies the hypotheses formulated in this article, and that is in line with the neo-functionalist theory and with current tendencies in institutional theory in organizations, refers to complex circularity, or what is here called recursivity. From this complex perspective the circle between individuals and the environment is not merely contingent (from individuals to the environment and from the environment to individuals), but is doubly contingent (Luhmann, 1976, 1995) and simultaneous (Giddens, 1984; Luhmann, 2002). Individuals and environments are mutually presumed (voluntarism and determinism, as much as the temporal moments that this assumes, become irrelevant categories). From this recursive perspective permanence and change both become possibilities and necessities within the understanding of organizational reality: both will occur the whole time and under all circumstances, allowing us to talk about predominance, but not exclusivity. This predominance in turn will depend on the cultural-cognitive elements accepted by the individuals in the systems and in the context (Giddens, 1984; Luhmann, 1995; Scott, 1995, 2001).

Also from this perspective, the expectation of control and the strategic use of fear and stress collapse, but it becomes possible to understand in a more appropriate way the dynamic that exists in organizations, where for various reasons the power to impose certain standards becomes improbable, or at least to understand some of the consequences of that imposition when it is still possible. This recursive possibility underlies the requisite stress principle proposed in this article.

Therefore, we can conclude that the requisite stress principle indicates that there is a similarity between levels of stress in the environment and in the organization and that this similarity, or equilibrium, is achieved using institutional mechanisms (mainly cognitive-cultural). It implies also that it is this vicious circle that has been leading to the institutionalization of stress as a normal condition of work, life in general and finally modern society itself, and that a decrease in levels goes through some mechanism of breaking this circle.

If the explanatory principle here proposed is confirmed, it will be also possible to indicate that the control of stress in organizations is as complex as the level of stress in society: its control will depend 
on the stress levels coming from society and this implies an extremely high level of complexity, and one that is certainly beyond any possibility of control within the sphere of organizations alone. In short, it curbs all attempts, perspectives or aspirations by management for controlling and using stress as a mechanism for managing and inducing actions.

This article has limited itself to putting forward propositions, and in this sense its intention, in the final analysis, has been to indicate the possibility of an alternative strand for exploring stress and other analytical categories that have up until now been mainly studied from a behavioral point of view. We have suggested the possibility of approaching them within the institutional and systemic sphere and, in doing so, to break the separation between individuals, systems and environments that is conventionally accepted as inexorable. This break, it should be noted, does not occur as far as the different reality of these elements as phenomena are concerned, but is an analytical and conceptual break of this difference. This seems to make it feasible, and even necessary, to understand individuals, systems and environments as inter-related, but always distinct parts of a whole.

Finally, Greek mythology, and more specifically the myth of Phobos and Deimos, can also offer us an enlightening metaphor about what we can conclude from this presentation of the requisite stress principle. The two brothers - Phobos and Deimos - sons of Mars, the God of War, represent the two faces of fear; fear as apprehension and fear as terror. We would suggest that organizations try to manage fear by inducing anxiety and apprehension while trying to control and avoid terror and panic. This is not an easy task, however, because as the myth of Phobos and Deimos reminds us, the two faces of fear always go hand-in-hand. To induce fear while trying to manage it can be a very risky undertaking.

\section{REFERENCES}

Albrecht, K. (1988). O gerente e o estresse. Rio de Janeiro: Jorge Zahar.

Ashby, W. R. (1957). Introduction to cybernetics. New York: John Wiley \& Sons.

Aubert, N. (1990). La nevrose professionnelle. In J. F. Chanlat (Ed.). LÍndividu dans l'organisation (pp. 163-194). Presses de L’Université Laval.

Ayres, K. (2000, setembro). Tecno-stress: um estudo em operadores de caixa de supermercado. Anais do Encontro Nacional da Associação Nacional de Pós-Graduação e Pesquisa em Administração, Florianópolis, SC, Brasil, 24.

Ayres, K., Brito, S., \& Feitosa, A. (1999, setembro). Stress ocupacional no ambiente acadêmico universitário: um estudo em professores universitários com cargos de chefia intermediária. Anais do Encontro Nacional da Associação Nacional de Pós-Graduação e Pesquisa em Administração, Foz do Iguaçu, PR, Brasil, 23.

Burns, T., \& Stalker, G. M. (1961). The management of innovation. London: Tavistock.

Caplan, R., \& Jones, K. (1975). Effects of work load, role ambiguity and type a personality on anxiety, depression and hearth rate. Journal of Applied Psychology, 60(6), 713-719.

Caplan, R. D., Cobb, S., French, J. R. P., Jr., Harrison, R.V., \& Pinneau, S. R., Jr. (1975). Job demands and worker health. Cincinnati: NIOSH.

Couto, H. (2000, setembro). Estresse e problemas de organização do trabalho numa unidade industrial recém-implantada - alta indicência de distúrbios de membros superiores como uma das 
conseqüências. Anais do Encontro Nacional da Associação Nacional de Pós-Graduação e Pesquisa em Administração, Florianópolis, SC, Brasil, 24.

Couto, H., \& Moraes, L. (1999, setembro). Stress no trabalho, fatores psicossociais e alta incidência de LER/DORT entre operadoras de caixa de supermercado: um estudo de caso. Anais do Encontro Nacional da Associação Nacional de Pós-Graduação e Pesquisa em Administração, Foz do Iguaçu, PR, Brasil, 23.

Cropanzano, R., Howes, J., Grandey, A., \& Toth, P. (1997). The relationship of organizational politics and support to organizational behaviors, attitudes, and stress. Journal of Organizational Behavior, 18(2), 159-180.

Crubellate, J. M. (2003, setembro). Conseqüências da modernidade: interpretando as reações culturais à racionalização administrativa em uma agência bancária. Anais do Encontro Nacional da Associação Nacional de Pós-Graduação e Pesquisa em Administração, Atibaia, SP, Brasil, 27.

Dejours, C. (1995). A Loucura no Trabalho. São Paulo: Cortez.

Dejours, C. (1999). A banalização da injustiça social. Rio de Janeiro: FGV.

DiMaggio, P., \& Powell, W. (1983). The iron cage revisited: institutional isomorphism and collective rationality. American Sociological Review, 48(2), 147-160.

DiMaggio, P., \& Powell, W. (1991). Introduction. In W. Powell \& P. DiMaggio (Eds.). The new institutionalism in organizational analysis (pp. 1-40). Chicago: The University of Chicago Press.

Enriquez, E. (1990). Da horda ao estado. Rio de Janeiro: Jorge Zahar.

Enriquez, E. (1992). l’organisation en Analyse. Paris: Presses Universitaires de France.

Fenwick, R., \& Tansig, M. (1994). The macroeconomic context of job stress. Journal of Health and Social Behavior, 35(3), 266-282.

Ferreira, L., \& Tomei, P. (2004, junho). Downsizing e estresse: um estudo de caso. Anais do Encontro Nacional de Estudos Organizacionais, Atibaia, SP, Brazil, 3.

Fontana, D. (1994). Estresse (2a ed.). São Paulo: Saraiva.

Giddens, A. (1984). The constitution of society. Berkeley: University of California Press.

Granovetter, M. (1985). Economic action and social structure: the problem of embeddedness. American Journal of Sociology, 91(3), 481-516.

Guller, I., Gillén, M., \& Machpherson, J. (2002). Global competition, institutions, and the diffusion of organizational practices: the international spread of ISO 9000 Quality Certificates. Administrative Science Quarterly, 47(2), 207-232.

Hirchhorn, L. (1997). Reworking. Philadelphia: Temple University Press.

Kahn, R., \& Byosiere, P. (1992). Stress in organizations. In M. Dunnette \& L. Hough (Eds.). Handbook of industrial and organizational psychology (pp. 571-650). Palo Alto, CA: Consulting Psychologists Press.

Kets de Vries, M., \& Miller, D. (1985). L'entreprise nevrosée (4th ed.). Paris: McGraw Hill. 
Lipp, M. (1996). Stress: conceitos básicos. In M. Lipp (Ed.). Pesquisas sobre stress no Brasil: saúde, ocupações e grupos de risco (pp. 17-31). Campinas: Papirus.

Luhmann, N. (1976). A general theory of organized social systems. In G. Hofstede \& S. Kassem (Eds.). European contributions to organization theory (pp. 96-113). Amsterdam: Van Gorcum.

Luhmann, N. (1995). Social systems. Stanford: Stanford University Press.

Luhmann, N. (2002). Theories of distinction: redescribing the descriptions of modernity. Stanford: Stanford University Press.

Mangematin, V., \& Thuderoz, C. (Eds.). (2003). Des mondes de confiance. Paris: CNRS Editions.

Matteson, M., \& Ivancevich, J. (1987). Controlling work stress: effective human resource and management strategies. London: Jossey-Bass Publishers.

Mckay, R. (2001). Organizational responses to an environmental bill of rights. Organization Studies, 22(4), 625-658.

Meyer, J., \& Rowan, B. (1977). Institutionalized organizations: formal structure as myth and ceremony. American Journal of Sociology, 83(2), 340-363.

Meyerson, D. (1994). Interpretations of stress in institutions: the cultural production of ambiguity and burnout. Administrative Science Quarterly, 39(4), 628-653.

Mizruchi, M., \& Fein, L. (1999). The social construction of organizational knowledge: a study of the uses of coercive, mimetic, and normative isomorphism. Administrative Science Quarterly, 44(4), 653-683.

Moraes, L. F., Pereira, L., Lopes, H., Rocha, D., Ferreira, S., \& Portes, P. (2001, setembro). Estresse e qualidade de vida no trabalho na Polícia Militar do Estado de Minas Gerais. Anais do Encontro Nacional da Associação Nacional de Pós-Graduação e Pesquisa em Administração, Campinas, SP, Brasil, 25.

Parasuraman, S., \& Alutto, J. (1984). Sources and outcomes of stress in organizational settings: toward the development of a structural model. The Academy of Management Journal, 27(2), 330-350.

Perrewe, P., \& Ganster, D. (1989). The impact of job demands and behavioral control on experienced job stress. Journal of Organizational Behavior, 10(3), 213-229.

Perrow, C. (1999). Normal accidents. New Jersey: Princeton University Press.

Powell, W., \& DiMaggio, P. (1991). Introduction. In W. Powell \& P. DiMaggio. The new institutionalism in organizational analysis (pp. 1-40). Chicago: The University of Chicago Press.

Rossini, A., Crubellate, J., \& Mendes, A. (2001). Reação cultural à aquisição: estudo do caso Santander/Noroeste. Revista de Administração Contemporânea, 5(1), 145-164.

Sant'Anna, A., Costa, R., \& Moraes, L. (2000, setembro). Qualidade de vida no trabalho: uma análise em unidades de ensino básico. Anais do Encontro Nacional da Associação Nacional de PósGraduação e Pesquisa em Administração, Florianópolis, SC, Brasil, 24.

Scott, W. R. (1992). Organizations (3rd ed.). Englewood Cliffs: Prentice Hall. 
Scott, W. R. (1995). Introduction: institutional theory and organizations. In W. R. Scott \& S. Christensen. The institutional construction of organizations: international and longitudinal studies (pp. xi-xxiii). Thousand Oaks: SAGE.

Scott, W. R. (2001). Institutions and organizations (2nd ed.). Thousand Oaks: Sage.

Scott, W. R., \& Meyer, J. (1983). The organization of societal sectors. In J. Meyer \& W. R. Scott. Organizational environments: ritual and rationality (pp. 129-153). Beverly Hills: Sage.

Scott, W. R., \& Meyer, J. (Eds.). (1994). Institutional environments and organizations: structural complexity and individualism. Thousand Oaks: SAGE.

Vasconcelos, I., \& Crubellate, J. (2004). Transitoriedade e permanência nas relações de trabalho. In F. Vasconcelos \& I. Vasconcelos (Eds.). Paradoxos organizacionais: uma visão transformacional (pp. 255-285). São Paulo: Thompson.

Weick, K., \& Sutcliffe, K. (2001). Managing the unexpected. San Francisco: Jossey-Bass. 